\title{
Tie the knot: building stronger consumers' attachment toward a brand
}

Article

Accepted Version

Ekinci, Y., Japutra, A. and Simkin, L. (2018) Tie the knot: building stronger consumers' attachment toward a brand. Journal of Strategic Marketing, 26 (3). pp. 223-240. ISSN 1466-4488 doi:

https://doi.org/10.1080/0965254X.2016.1195862 Available at https://centaur.reading.ac.uk/68131/

It is advisable to refer to the publisher's version if you intend to cite from the work. See Guidance on citing.

To link to this article DOI: http://dx.doi.org/10.1080/0965254X.2016.1195862

Publisher: Taylor \& Francis

All outputs in CentAUR are protected by Intellectual Property Rights law, including copyright law. Copyright and IPR is retained by the creators or other copyright holders. Terms and conditions for use of this material are defined in the End User Agreement.

\section{www.reading.ac.uk/centaur}

\section{CentAUR}

Central Archive at the University of Reading 
Reading's research outputs online 


\title{
Tie the knot: building stronger consumers' attachment toward a brand
}

\author{
Arnold Japutra $^{\mathrm{a}}$, Yuksel Ekinci ${ }^{\mathrm{b}}$ \& Lyndon Simkin ${ }^{\mathrm{c}}$ \\ aDepartment of Management, Tarumanagara University, Jakarta, Indonesia \\ ${ }^{b}$ Henley Business School, University of Reading, Reading, UK \\ ${ }^{\mathrm{c} C o v e n t r y ~ B u s i n e s s ~ S c h o o l, ~ C o v e n t r y ~ U n i v e r s i t y, ~ C o v e n t r y, ~ U K ~}$
}

To cite this article: Arnold Japutra, Yuksel Ekinci \& Lyndon Simkin (2016): Tie the knot: building stronger consumers' attachment toward a brand, Journal of Strategic Marketing, DOI: 10.1080/0965254X.2016.1195862

\begin{abstract}
Extant research has promoted the importance and seeking to establish a deeper understanding of brand loyalty. However, it still remains elusive and uncertain. A study with more than 1,500 CEOs worldwide believes that creating a bond with consumers and continuing to learn how to strengthen the bond are essential for realizing strategies and delivering on shareholder expectations. Not surprisingly, firms and researchers are seeking ways to build a stronger connection with consumers, because such attachment acts as a key requisite in a firm's success. Consequently, understanding how marketers can intensify the attachment is important. This article offers a framework for building stronger consumers' attachment and testing it based on a survey of 432 participants. Four factors are deemed to be important: ideal self-congruence, sensory experience, responsiveness, and CSR beliefs. Attachment influences loyalty and resilience to negative information. Additionally, attachment fully mediates ideal self-congruence and responsiveness to loyalty, as well as ideal self-congruence and sensory experience to resilience to negative information.
\end{abstract}

Keywords: Brand Attachment, Ideal Self-Congruence, Sensory Experience and Responsiveness, CSR Beliefs, Brand Loyalty, Resilience to Negative Information 
Tie the knot: building stronger consumers' attachment toward a brand

\section{Introduction}

Creating and maintaining brand attachment may well be part of the solution to a growing concern regarding observed reducing levels of brand loyalty. CEOs from various firms and industries highlighted the importance of learning ways to strengthen their bond with consumers (IBM, 2010). This requires a clearer understanding of the components of brand attachment and how best to nurture this emotional and cognitive bonding between consumers and their preferred brands. An extensive global survey conducted by Ernst and Young (2011) found that consumers are exhibiting lower brand loyalty, which increases the challenges for businesses to find new ways to hook their customers.Extant research has established the link between satisfaction and loyalty (e.g. Anderson \& Srinivasan, 2003). However, Reichheld (2003) notes that satisfaction lacks the consistency in demonstrating connection to loyalty. Chandrashekaran, Rotte, Tax, and Grewal (2007) urge researchers to focus on the value of monitoring consumers' relationship quality (e.g.attachment) since it has a profound impact on favorable consumer behaviors. Reibstein,Day, and Wind (2009, p. 1) construe that the focus of the field of marketing is 'about the connection of the firm to its customers'. It has been proposed that attachment encompasses various constructs (e.g. attitude) in explaining higher level of consumers' behaviors which reflect investment of resources (e.g. Park \& MacInnis, 2006). An enduring relationship (e.g. love for brands) indicates attachment as one of the crucial components (Batra, Ahuvia, \& Bagozzi, 2012). Thus, Park, MacInnis, Priester, Eisingerich, and 
Iacobucci (2010, p. 14) urge researchers to examine 'how marketers can enhance brand attachment'. To that end, this research offers a framework on how to build stronger consumers' attachment. Recently academics have advocated that brand attachment is a crucial concept in relationship marketing, increasing emotional bonding and loyalty (Schmalz \& Orth, 2012). Practitioners have also been putting efforts into building brand attachment. For instance, Google created an advertisement - known as the Google India Ad - that sparks emotion of its viewers. This highlights that practitioners consider emotionally attaching consumer to a brand to be of importance. So how do marketers build stronger brand attachment? Does brand attachment increase the predictive power of favorable consumer behaviors? This article addresses these questions by developing and testing a conceptual framework of brand attachment. Building consumer-brand relationships is important to the long-term prosperity of brands and plays a role in today's brand success (Veloutsou \& Moutinho, 2009). Fournier (1998) found that brands adhere to systems that consumers create to give meaning to their lives. As a result, revenue and profit from strong attachment are less vulnerable to disruption (Grisaffe \& Nguyen, 2011). Strong attachment toward a brand is crucial for the success of brand extensions (Fedorikhin, Park, \& Thomson, 2008). In consideration of this, a growing body of research (e.g. Orth, Limon, \& Rose, 2010) has focused on what it means for consumers to connect with brands and the implications of that attachment.

Research on brand attachment is relatively new, as its conceptualization is still developing. Thomson, MacInnis, and Park (2005) conceptualized brand attachment as embodying emotional bonding. However, later research (Park et al., 2010) extended the conceptualization of brand attachment to also embody cognitive bonding. Research on brand attachment has usually been restricted to single-category studies, for example in the context of retailing (e.g. Orth et al., 2010). Nevertheless, Park et al. (2010) noted that further research is needed toward 
better understanding of antecedents and consequences of brand attachment across many domains.

Given this backdrop, our study builds on previous work and makes three contributions.

First, it extends the single-category examination of brand attachment by introducing a multidimensional framework for building brand attachment. Most existing research encapsulates brand attachment largely based on emotions, such as passion and self-connection (e.g. Park et al., 2010; Thomson et al., 2005). The conceptualization and measurement of brand attachment in this study fosters both affective and cognitive bonding. Hence, the outcome of the conceptual synthesis includes four affective and cognitive dimensions: ideal selfcongruence, sensory brand experience, brand responsiveness, and corporate social responsibility (CSR) beliefs. Second, this study responds to the call of Schmitt (2013), which suggests that the relationship between brand experience and brand attachment is understudied. Brakus, Schmitt,and Zarantonello (2009) propose that in the long run, brand experience may lead to attachment. This research shows that brand attachment is positively influenced by sensory brand Finally, the effects of brand attachment on brand loyalty and resilience to negative information are examined. This research demonstrates that these behavioral intentions are mediated by brand attachment. Brand responsiveness does not directly influence brand loyalty, whereas sensory brand experience does not directly influence resilience to negative information. Concurrently, ideal self-congruence does not have a direct impact on these two behaviors. Increasing these dimensions will increase the strength of the attachment, which will lead to the behaviors. This study confirms the proposition suggested by Bhattacharya and Sen (2003) that resilience to negative information is the consequence of strong consumers' identification with the brand.

\section{Theoretical background and hypotheses development}




\section{The research model}

In order to create meanings for building their identity (e.g. self-definitional value), consumers build relationships with brands (Fournier, 1998). Recently, brand attachment has received much attention because it is a salient concept in explaining higher level of consumers' behavior (cf. Park \& MacInnis, 2006). In predicting a higher level of consumer's behavior, which reflects commitment to the brand and use of significant resources (time, money, and reputation), brand attachment is more plausible than brand attitude (Park et al., 2010). According to these authors, the reason is because attachment captures heart and mind share of a consumer, whereas attitude only captures the mind share.

Brand attachment has been conceptualized to encapsulate emotional bonding, consisting of affection, passion, and connection (Thomson et al., 2005). Subsequent to that, brand attachment is argued to not only capture emotional but also cognitive bonding, reflecting brand-self connection - the belief hold by consumers on the relevance between the brand and 'their self' (Fedorikhin et al., 2008), similar to self-brand connections research (e.g. Edson Escalas, 2004) . More recently, brand prominence - the salience of the brand-self connection through perceived ease and frequency brought into consumers' mind - has been added to the conceptualization (Park et al., 2010). Consistent with the previous literature, brand attachment in this research refers to the strength of the affective and cognitive bond between consumers' self and the brand. Although the construct of brand attachment shares many similarities with other constructs, such as consumer-brand identification (CBI), it has been noted that $\mathrm{CBI}$ is narrower in the sense that it excludes self-brand connections, but is an 
integral part of brand attachment (Stokburger-Sauer, Ratneshwar, \& Sen, 2012). The following research model, as shown in Figure 1, is developed to guide this study. In Figure 1, the overall brand attachment is influenced positively by four factors: ideal self-congruence $(\mathrm{H} 1)$, sensory brand experience $(\mathrm{H} 2)$, brand responsiveness $(\mathrm{H} 3)$, and CSR beliefs (H4). Overall brand attachment fully mediates the relationships and leads to two consequences: brand loyalty and resilience to negative information. Two psychological theories act as the central assumptions in building the research model: self-concept (cf. Reed, 2002) and attachment theory (cf. Schmalz \& Orth, 2012). Self-concept is conceptualized as having several components, including the ideal self, with self-enhancement as the underlying motive (Sirgy, 1982). The self-enhancement motive guides individuals to increase their selfesteem, for instance, being acknowledged as a socially responsible person. Hence, ideal selfcongruence and CSR beliefs appear in our model because of the self-enhancement motive.

[Figure 1 Here.]

In attachment theory, Bowlby (1969) argues that proximity seeking causes a person to develop emotional bonds with an attachment figure. However, Hazan and Shaver (1994) state that proximity seeking itself is not enough in explaining the bond. They suggest that familiarity and responsiveness are fundamental to attachment. In a study of human brands, Thomson (2006) indicates that autonomy, relatedness, and not suppressing competence act as predictors of separation distress - which has been considered as an indicator of attachment security (Hazan \& Shaver, 1994). Additionally, consumers are more likely to identify with a brand if they have greater memorable experiences with the brand (StokburgerSauer et al., 2012). Therefore, sensory brand experience and brand responsiveness are included as antecedents of brand attachment. 
This study put forward brand loyalty and resilience of negative information as the consequences of brand attachment. Extant research (e.g. Japutra, Ekinci, \& Simkin, 2014; Orth et al., 2010; Vlachos, Theotokis, Pramatari, \& Vrechopoulos, 2010) has shown that brand attachment positively affects brand loyalty (H5). Additionally, we test the proposition from Bhattacharya and Sen (2003), who argue that consumer-company identification leads to resilience to negative information. Hence, we posit that brand attachment will positively influence resilience to negative information (H6). In order to examine the mediational role of brand attachment, a partial mediation model is developed as shown in Figure 2.

[Figure 2 Here].

The partial mediation model introduces two sets of additional hypotheses. The first set of hypothesis $(\mathrm{H} 7 \mathrm{a}-\mathrm{H} 7 \mathrm{~d})$ indicates that there is direct relationship between the four antecedents of brand attachment and brand loyalty; whereas the second set of hypothesis (H8a-H8d) indicates that there is direct relationship between the four antecedents of brand attachment and resilience to negative information.

\section{Hypotheses}

\section{Self-congruence and brand attachment}

The concept of self-congruence refers to the degree to which a brand's image is congruent with consumers' actual or ideal self-concept (Sirgy, 1982). Actual self-concept relates to the consumers' actual reality, whereas ideal self-concept relates to the consumers' aspiration of their future condition. The current research focuses on ideal self-congruence, since it has 
been found that ideal self-congruence to be consistently stronger compared to actual self-congruence in predicting favorable brand evaluations (Graeff, 1996). In conjunction, a study in hospitality confirms that ideal self-congruence and not actual self-congruence positively influences consumer satisfaction (Ekinci, Dawes, \& Massey, 2008). Following previous research (Aaker, 1999; Sirgy, 1982), in this study ideal self-congruence is defined as the fit between the brand and consumers' ideal self.

The basis of the notion of ideal self-congruence is that individuals purchase brands in order to enhance their self-esteem (Aaker, 1999). A self-enhancement motive (e.g. self-esteem) urges consumers to pursue their ideal-self, which leads consumers to choose or purchase a brand that can help them in projecting their ideal-self. Brands with higher capabilities to enhance consumers' ideal-self are likely to exhibit being more preferable (Hong \& Zinkhan, 1995; Escalas \& Bettman, 2005). A high level of ideal self-congruence has been shown to influence a consumer's brand attitude and brand choice (Mehta, 1999; Sirgy, Grewal, Mangleburg, Park, Chon, Clairbone, Johar \& Berkman, 1997). Kim, Lee and Ulgado (2005) show that congruity between the ideal-self and brand personality positively influences two aspects of brand attachment - emotional dependence and separation anxiety.

A high level of ideal self-congruence has been shown to influence a consumer's brand attitude and brand choice (Mehta, 1999; Sirgy et al., 1997). Kim, Lee, and Ulgado (2005) identify that congruity between ideal self with brand personality positively influences emotional dependence and separation anxiety. Consumers have the motivations to enhance their self-esteem because of self-enhancement motive. This will urge consumer to purchase brands that represent their aspirations and dreams (ideal self ), which will lead to stronger passion, affection, and connection (Malär, Krohmer, Hoyer, \& Nyffenegger, 2011). The more 
the brand is similar to the self, the more the consumer will identify with that brand (StokburgerSauer et al., 2012), creating stronger bonding. By purchasing a brand that provides self-esteem enhancement, consumers may not just increase positive feelings toward the brand but also their attachment with the brand.

H1: Ideal self-congruence is positively related to brand attachment.

\section{Sensory brand experience and brand attachment}

Attachment theory put forward familiarity as fundamental to determine attachment strength (Hazan \& Shaver, 1994). Alba and Hutchinson (1987) note that familiarity is the collection of direct and indirect experiences with the brand. Consumers become familiar with a brand because of their experiences with the brand. Brakus et al. (2009) mention that over time, experiences with the brand may result in emotional attachment. Stokburger-Sauer et al. (2012) show that memorable brand experience leads to consumer-brand identification. Park, Jaworski and MacInnis (1986) note the importance of using sensory experiences in building brand image. Two studies display that sensory experience helps in the creation of bonding between participants. Celsi, Rose, and Leigh (1993) show that the activities on high-risk sport (sky diving) containing pleasure and enthusiasm, as well as the sense of thrill

and excitement, give the participants extraordinary sensory experiences. These authors propose that at the individual level, flow experience occurs, and this flow experience profoundly satisfying by accommodating a sense of self and self-efficacy - establishes bonding. Research on river rafting (Arnould \& Price, 1993) shows that sensory experience plays a role in setting up the bonding. Mixed sensations from the experience, such as communion with nature, fear, danger, mastery, and so forth, support a consumer's attachment with other participants and the activity. Our study argues that sensory brand experiences can also increase 
the likelihood for a connection between the self and the brands to occur. This study also argues that sensory brand experience will evoke positive memories and - over time - these memories will increase the saliency of the brand.

H2: Sensory brand experience is positively related to brand attachment.

\section{Brand responsiveness and brand attachment}

Not only familiarity, responsiveness has also been considered as the foundation of our attachment with another (Hazan \& Shaver, 1994). La Guardia and Patrick (2008) believe that a partner that responds in ways that satisfied the three basic psychological needs (autonomy, relatedness, and competence) is a responsive partner. As has been discussed above, brand responsiveness refers to the condition where the brand is able to provide the sense of autonomy, relatedness, and competence for the consumers.

For relationships to function, it is prominent for relational partner to reinforce the other's sense of autonomy, relatedness, and competence (La Guardia \& Patrick, 2008). It has been shown that fulfilling autonomy, relatedness, and competence lead to stronger attachment (La Guardia, Ryan, Couchman, \& Deci, 2000). Patrick, Knee, Canevello, and Lonsbary (2007) found evidence that the fulfillment of these three basic psychological needs is related to attachment. Further, in a study about brands (Thomson, 2006), it has been shown that consumers can become strongly attached to brands, if their sense of autonomy and sense of relatedness are enhanced while not restraining their sense of competence.

H3: Brand responsiveness is positively related to brand attachment. 
It has been noted that CSR activities for a firm are not only for the sake of 'doing good' and 'the right thing to do', but also lead to 'doing better', since consumers are particularly susceptible to these activities (Bhattacharya \& Sen, 2004). Additionally, Holt, Quelch, and Taylor (2004) reveal that consumers all over the world associate global brands with three characteristics: (1) quality signal, (2) global myth, and (3) social responsibility.

Brown and Dacin (1997) indicate that CSR associations play a role in influencing consumers' product evaluations. In a study of global brands (Holt et al., 2004), social responsibility has been found to explain brand preferences. These authors indicate that consumers are convinced that global brands have the responsibilities to endeavor social issues. Vlachos and Vrechopoulos (2012) show that CSR associations positively influence consumerretailer love. Du, Bhattacharya, and Sen (2007) display that stronger CSR beliefs lead to greater identification with the brand. In addition, Bhattacharya and Sen (2004) argue that the outcome of CSR activities is a sense of attachment toward the brand.

H4: CSR beliefs are positively related to brand attachment.

\section{Brand attachment and brand loyalty}

Bhattacharya and Sen (2003) propose that greater loyalty, which is immune to disturbances and variations, is the result of consumers' identification with the company. Research shows that emotional brand attachment leads to the intention to purchase and the intention to recommend (e.g. Orth et al., 2010). It has also been shown that brand-self connection is positively related to behavioral intentions, such as likelihood of trial, purchase, and so forth (Edson Escalas, 2004). Recent research reveals that brand attachment is an important predictor of purchase behavior (Japutra et al., 2014; Park et al., 2010). Finally, Stokburger-Sauer et al. 
(2012) reported that consumer-brand identification is positively associated with brand loyalty and brand advocacy.

H5: Brand attachment is positively related to brand loyalty.

\section{Brand attachment and resilience to negative information}

Bhattacharya and Sen (2003) propose that the more strongly consumers associate themselves with a brand, the higher is their resilience to negative information towards the brand. We argue that when consumers identify themselves with a brand, they consider the brand to be similar to themselves, supporting being forgiving towards the brand; just as they are forgiving themselves or partners. Park et al. (2010) indicate that stronger attachment with the brand leads to consumers' defending the brand when brand makes a mistake. When others speak poorly about the brand, they consider that other people speak poorly about them too, which increases their self-defense mechanism. Strong attachment dissipates consumers' judgment towards the brand's unethical behaviors (Schmalz \& Orth, 2012).

H6: Brand attachment is positively related to resilience to negative information.

\section{Research method}

\section{Sample}

The survey data, which based on 432 respondents in the UK, were analyzed. Most of the participants were women (61.83\%), British (76.58\%), and worked as professionals (27.40\%). In terms of age group, $21.03 \%$ of the participants were in the 16-24 range, $16.36 \%$ of the participants were in the $25-34$ range, and $18.93 \%$ of the participants were in the $35-44$ range. As many as $31.85 \%$ of the participants reported to have obtained undergraduate 
degree. Participants reported their income, which ranged from less than $£ 10,000$ to more than $£ 100,000$, with most of them obtaining less than $£ 10,000$ (27.35\%) and $£ 20,000$ to $£ 29,999(20.91 \%)$.

The brands listed were diverse and from a mix of categories, including electronics (Apple), fashion retailers (Zara), car manufacturers (BMW), airlines (British Airways), food and beverages (Coca-Cola), and so on. Most of the participants (53.83\%) had been using the brand that they chose to focus on for 10 years or above. In terms of purchasing frequency, most of the participants $(24.13 \%)$ purchased the brand several times a year and as many as $33.56 \%$ of the total participants mentioned that they purchased the brand less than a week ago.

\section{Measures}

All of the measures within our study are derived from previous studies: ideal self-congruence (Malär et al., 2011; Sirgy et al., 1997), brand experience (Brakus et al., 2009), brand responsiveness (e.g. Thomson, 2006), CSR beliefs (Du et al., 2007; Vlachos \& Vrechopoulos, 2012), brand attachment (Park et al., 2010), brand loyalty (e.g. Yim, Tse \& Chan, 2008), and resilience to negative information (e.g. Xie \& Peng, 2009). All constructs were measured on 7point Likert scales unless stated otherwise.

Ideal self-congruence was measured using 3 items (e.g. "[This brand] is similar to the person I would like to be.”). Measurement of ideal self-congruence used the method introduced by Sirgy et al. (1997) and later used by Nam et al. (2011), which requires a scenario type direction before answering the three scaled items. The scenario type direction was as follows:

"Take a moment to think about your favorite brand. Think about the kind of person who typically uses this brand. Imagine this person in your mind and then describe this person using one or more personal adjectives such as, stylish, 
classy, masculine, sexy, old, athletic, or whatever personal adjectives you can use to describe the typical user of this brand."

Sensory brand experience was measured using 3 items (e.g. '[This brand] makes a strong impression on my visual sense or other senses.') on 7-point Likert scales where 1 = 'strongly disagree' and $7=$ 'strongly agree', respectively. Brand responsiveness was measured using 4 items (e.g. 'When using [this brand], I feel free to be who I am.') on 7-point Likert scales, where $1=$ 'strongly disagree' and $7=$ 'strongly agree', consisting of autonomy, relatedness, and competence. CSR beliefs were measured using 3 items (e.g. '[This brand] is a socially responsible brand.') on 7-point Likert scales where $1=$ 'strongly disagree' and $7=$ 'strongly agree'. Brand attachment was measured using 4 items (e.g. 'To what extent is [this brand] part of you and who you are?'), on 11-point Likert scales, where $0=$ 'not at all' and $10=$ 'completely'.

Brand loyalty was measured using 3 items (e.g. 'I will continue to purchase [this brand] even if it increases price.'), and resilience to negative information was measured using 3 items (e.g. 'I forgive [this brand] when it makes mistakes.'), on 7-point Likert scales where $1=$ 'not very likely' and $7=$ 'very likely'. The details on the scale measurement can be seen in Appendix.

\section{Results}

\section{Validity and reliability of measures}

Before analyzing the model, normality tests were conducted in order to confirm the multivariate normality of the data (Hair, Black, Babin and Anderson, 2010). The normality tests were conducted using: (1) the values of skewness and kurtosis, and (2) graphical analysis (normal probability plot). The results from both tests suggested that the data distribution was normal. The skewness and kurtosis values were around the absolute value of +1 and -1 . 
Average variance extracted (AVE) exceeding 0.50 provides support for convergent validity and AVE greater than the squared correlations indicates discriminant validity (Fornell \& Larcker, 1981; Hair et al., 2010). To assess reliability, we used both Cronbach's Alpha ( $\alpha)$ and Composite Reliability (CR) with a rule of thumb of these scores are above 0.7 . Table 1 exhibits the details on the alpha, CR, and AVE scores.

Table 1 here.

Table 1 reveals that all of the constructs achieved convergent and discriminant validity, since the AVE scores were 0.5 or above and greater than the SIC scores. Composite reliability and Cronbach's alpha indicated that reliability was achieved. The measurement model produced the acceptable goodness-of-fit-measures $\left(\chi^{2}{ }_{(209)}=401.81 ; p<0.01, \chi^{2} / \mathrm{df}=1.92, \mathrm{GFI}=0.93, \mathrm{NFI}\right.$ $=0.92, \mathrm{CFI}=0.96, \mathrm{RMSEA}=0.05$ and SRMR $=0.04)$. The $\mathrm{p}$-value for $\chi^{2}$ test was statistically significant because this test is sensitive to sample size (Hair et al., 2010). Hair et al. (2010) suggest to check the normed chi-square (a ratio of $\chi^{2}$ to the degrees of freedom), where the value of less than 3 is associated with good fit. Table 2 shows the results of the structural equations analyses for the full and partial mediation models.

Table 2 here.

The results of the full mediation model indices support a good overall model fit $\left(\chi^{2}(218)=442.68\right.$; $p<0.01, \chi^{2} / \mathrm{df}=2.03, \mathrm{GFI}=0.92, \mathrm{NFI}=0.91, \mathrm{CFI}=0.95, \mathrm{RMSEA}=0.05$ and $\left.\mathrm{SRMR}=0.06\right)$. The results of the partial model indices also support a good overall model fit $\left(\chi_{(210)}^{2}=407.71\right.$; $p<0.01, \chi^{2} / \mathrm{df}=1.94, \mathrm{GFI}=0.93, \mathrm{NFI}=0.91, \mathrm{CFI}=0.96, \mathrm{RMSEA}=0.05$ and $\left.\mathrm{SRMR}=0.05\right)$. 
Results from the $\chi^{2}$ difference test (Brown, Mowen, Donovan \& Licata, 2002) suggest that the partial mediation model provides the best fit for the data $\left(\Delta \chi^{2}(8)=34.97 ; p<0.01\right)$.

Hierarchical regression tests were conducted to find out whether brand attachment mediation accounts for a greater proportion of variance explained in brand loyalty and resilience to negative information (Brown et al., 2002). For both brand loyalty and resilience to negative information, the improvement in the $\mathrm{R}^{2}$ from including brand attachment was statistically significant (brand loyalty: $\Delta \mathrm{R}^{2}=0.03, \Delta \mathrm{F}_{1,426}=16.29, p<0.01$; resilience to negative information: $\left.\Delta \mathrm{R}^{2}=0.03, \Delta \mathrm{F}_{1,426}=16.59, p<0.01\right)$.

The model fits for both mail and Internet surveys were checked. For the full mediation model, both of the surveys produced a good fit (mail survey: $\chi^{2}(218)=426.67 ; p<0.01, \chi^{2} / \mathrm{df}=1.96$, $\mathrm{GFI}=0.89, \mathrm{NFI}=0.87, \mathrm{CFI}=0.93, \mathrm{RMSEA}=0.06$ and $\mathrm{SRMR}=0.06 ;$ internet survey: $\chi^{2}{ }_{(218)}$ $=304.17 ; p<0.01, \chi^{2} / \mathrm{df}=1.40, \mathrm{GFI}=0.85, \mathrm{NFI}=0.84, \mathrm{CFI}=0.95, \mathrm{RMSEA}=0.05$ and SRMR $=0.08$ ). For the partial mediation model, both of the surveys also produced a good fit (mail survey: $\chi^{2}(210)=399.61 ; p<0.01, \chi^{2} / \mathrm{df}=1.90, \mathrm{GFI}=0.89, \mathrm{NFI}=0.88, \mathrm{CFI}=0.94$, $\mathrm{RMSEA}=0.06$ and SRMR $=0.05$; internet survey: $\chi^{2}{ }_{(210)}=285.44 ; p<0.01, \chi^{2} / \mathrm{df}=1.36, \mathrm{GFI}$ $=0.86, \mathrm{NFI}=0.85, \mathrm{CFI}=0.95, \mathrm{RMSEA}=0.05$ and $\mathrm{SRMR}=0.07)$.

In order to ensure validity of the model, the model fit statistics for male and female groups were checked. For the full mediation model, both groups produced a good fit (male: $\chi^{2}(218)=381.53$; $p<0.01, \chi^{2} / \mathrm{df}=1.75, \mathrm{GFI}=0.84, \mathrm{NFI}=0.80, \mathrm{CFI}=0.90, \mathrm{RMSEA}=0.07$ and $\mathrm{SRMR}=0.08$ female: $\chi^{2}{ }_{(218)}=388.48 ; p<0.01, \chi^{2} / \mathrm{df}=1.78, \mathrm{GFI}=0.89, \mathrm{NFI}=0.88, \mathrm{CFI}=0.94, \mathrm{RMSEA}=$ 0.06 and SRMR $=0.06$ ). For the partial mediation model, both groups also produced a good fit (male: $\chi^{2}{ }_{(210)}=353.57 ; p<0.01, \chi^{2} / \mathrm{df}=1.68, \mathrm{GFI}=0.85, \mathrm{NFI}=0.82, \mathrm{CFI}=0.91, \mathrm{RMSEA}=$ 
0.07 and SRMR $=0.07 ;$ female: $\chi^{2}(210)=371.62 ; p<0.01, \chi^{2} / \mathrm{df}=1.77, \mathrm{GFI}=0.90, \mathrm{NFI}=0.88$, $\mathrm{CFI}=0.94, \mathrm{RMSEA}=0.05$ and $\mathrm{SRMR}=0.05)$.

\section{Hypothesis testing}

The findings support $\mathrm{H} 1$, which predicts that ideal self-congruence is positively related to brand attachment $(\mathrm{SPC}=.22, \mathrm{t}=4.03, \mathrm{p}<.01)$. This means that greater ideal self-congruence will result in stronger brand attachment. $\mathrm{H} 2$ predicts that sensory brand experience is positively associated with brand attachment, and the results support the prediction (SPC $=.15$, $\mathrm{t}=2.56, \mathrm{p}<.05)$. This result indicates that higher sensory experiences with the brand will increase brand attachment. In practice, marketers need to communicate the brand's images or personalities that could cater to their consumers' ideal self. Marketers also need to deliver the brand's experiences that induce feelings and thoughts through their consumers' five senses.

H3 states that brand responsiveness is positively associated with brand attachment; the results support this hypothesis $(\mathrm{SPC}=.38, \mathrm{t}=5.78, \mathrm{p}<.01)$. The greater the brand's responsiveness through fulfilling consumers' sense of autonomy, relatedness and competence will increase brand attachment. The results also support H4, which predicts that CSR beliefs are positively related to brand attachment $(\mathrm{SPC}=.12, \mathrm{t}=2.54, \mathrm{p}<.05)$. This result indicates that higher CSR beliefs will result in stronger brand attachment. Generally speaking, a brand should be proactive in creating or supporting their consumers' sense of autonomy, relatedness, and competence. Apart from that, marketers need to increase the consumers' awareness toward their CSR activities.

Hypotheses $\mathrm{H} 1$ to $\mathrm{H} 4$ were tested, to address the question of how marketers build stronger 
brand attachment. The findings emphasize the importance of four cognitive and affective dimensions as drivers of brand attachment (almost half of the variance in brand attachment can be explained), namely ideal self-congruence, sensory brand experience, brand responsiveness, and CSR beliefs. Those who had greater ideal self-congruence, sensory brand experience, brand responsiveness, and CSR beliefs were more likely to have a stronger attachment with the brand. The results also suggest that, of the four factors, brand responsiveness may be particularly important in the context of brand attachment.

H5 and H6 state that brand attachment exerts a positive influence on brand loyalty and resilience to negative information, respectively. The result indicates that both brand loyalty $(\mathrm{SPC}=.36, \mathrm{t}=6.28, \mathrm{p}<.01)$ and resilience of negative information $(\mathrm{SPC}=.37, \mathrm{t}=6.33, \mathrm{p}<$ $.01)$ are positively associated with brand attachment.

Hypotheses H7a through H7d suggest that brand attachment mediates the effect of the independent variables on brand loyalty. The results, as shown in Table 2, indicate that sensory brand experience $(\mathrm{SPC}=.23, \mathrm{t}=3.07, \mathrm{p}<.01)$ and CSR beliefs $(\mathrm{SPC}=.17, \mathrm{t}=2.77, \mathrm{p}<.01)$ directly influence brand loyalty. These results show that brand attachment partially mediates sensory brand experience and CSR beliefs on brand loyalty. However, the results display that ideal self-congruence $(\mathrm{SPC}=-.06, \mathrm{t}=-.82, \mathrm{p}>.10)$ and brand responsiveness $(\mathrm{SPC}=-.06, \mathrm{t}$ $=-.73, \mathrm{p}>.10$ ) do not directly influence brand loyalty, which means brand attachment fully mediates the relationships between ideal self-congruence and brand loyalty, as well as the relationships between brand responsiveness and brand loyalty.

Hypotheses H8a through H8d suggest that brand attachment mediates the effect of the independent variables on resilience to negative information. The results, as shown in Table 
2 , indicate that brand responsiveness $(\mathrm{SPC}=.21, \mathrm{t}=2.51, \mathrm{p}<.05)$ and CSR beliefs $(\mathrm{SPC}=.20$, $\mathrm{t}=3.26, \mathrm{p}<.01)$ directly influence resilience to negative information. These results show that brand attachment partially mediates the two variables on resilience to negative information. However, the results display that ideal self-congruence $(\mathrm{SPC}=-.10, \mathrm{t}=-1.40, \mathrm{p}>.10)$ and sensory brand experience $(\mathrm{SPC}=-.03, \mathrm{t}=-.40, \mathrm{p}>.10)$ do not directly influence resilience to negative information, which means brand attachment fully mediates the relationships between ideal self-congruence and resilience to negative information as well as the relationships between sensory brand experience and resilience to negative information.

The above hypotheses were tested to address the question on whether brand attachment increases the predictive power of favorable consumer behaviors. Brand attachment was found to mediate the relationships of the four independent variables to the two dependent variables. In order to achieve loyalty and resilience to negative information, marketers need to focus on building stronger brand attachment by focusing on the four independent variables.

\section{Conclusion}

\section{Contribution to theory}

Generally speaking, this research adds to the growing body of knowledge on the topic of consumer-brand relationships literature specifically brand attachment. The results provide convincing empirical support for the research model, offering four important drivers of brand attachment. Almost half of the variance of brand attachment (44\%) is explained by the four independent variables: ideal self-congruence, sensory brand experience, brand responsiveness, and CSR beliefs. Additionally, the results showed a significant relationship between brand 
attachment and two favorable consequences, namely brand loyalty and resilience to negative information.

Furthermore, this study provides an integrative understanding of the drivers of brand attachment, fostering brand-self connection and brand prominence - answering the call from Park et al. (2010). The results depicted that ideal self-congruence is positively associated with brand attachment. Previous studies (e.g. Kressmann et al., 2006; Nam et al., 2011) show that ideal self-congruence has a direct positive effect toward brand loyalty. However, our study revealed that ideal self-congruence is fully mediated by brand attachment. This means increasing ideal self-congruence does not directly increase brand loyalty; higher ideal self-congruence leads to stronger brand attachment, which leads to brand loyalty. For instance, if the ideal self and brand's image fit is high, it does not mean that consumers will have higher intention on forgiving the brand for its mistakes. Higher fit increases their bonding with the brand; at some point, the bonding can be considered to be strong, with the tendency to forgive the brand for its mistakes.

The current article also demonstrates the positive link between sensory brand experience and brand attachment. This empirically confirms the proposition of Schmitt (2013) that brand experience is one of the key determinants of brand attachment. Apart from that, the results confirm a previous study (Brakus et al., 2009), in that brand experience directly leads to brand loyalty. Besides, it has been shown that brand attachment fully mediates the relationships between sensory brand experience and resilience to negative information. The higher the sensory experiences, the greater the bonding between a consumer and the brand, which increases a consumer's forgiveness toward the brand. 
Based on the results, the strongest driver of brand attachment is brand responsiveness, which confirms Thomson's (2006) study that fulfilling the three basic psychological needs is important in building attachment. Contrary to Thomson's (2006) findings indicating that competence is insignificant in the creation of strong attachment, our work found that competence - together with autonomy and relatedness - is an important indicator in creating strong attachment. This is in alignment with Patrick et al.'s (2007) study about interpersonal relationships that shows individuals who have greater need fulfillment, encompassing autonomy, relatedness, and competence are more motivated to be in the relationship. An increasing sense of competence - together with autonomy and relatedness - is also an important factor in building more secure attachment. Additionally, this study shows that CSR associations build a stronger bond between consumer and the brand. This extends Du et al.'s (2007) study, which found CSR beliefs to be important in building consumer-company identification. CSR beliefs are salient in building consumer-brand connections and a driver of brand prominence.

To the best of our knowledge, previous research has yet to empirically test the link between brand attachment and resilience to negative information. This paper is the first to show that stronger brand attachment leads to higher resilience toward negative information. It is evident that when a strong bond between the consumer and brand has been established, they are more likely to forgive the brand when it conducted mistakes and violations. Bhattacharya and Sen (2003) propose that the higher the company-consumer identification will result in greater resilience to negative information. It has also been shown that brand attachment influences consumers' ethical judgment (Schmalz \& Orth, 2012). This occurs because consumers think the brand as the reflection of their selves and become more forgiving. 
However, it should be noted that this effect can be attenuated when the magnitude of the mistakes and violations are beyond consumers' zone of tolerance (Bhattacharya \& Sen, 2003). This result offers support to a study (Lin \& Sung, 2014) reporting that brand identity fusion is more predictive and enduring - compared to brand identification - in explaining pro-relationship behaviors in the face of brand transgressions. Furthermore, the relationships between ideal self-congruence and sensory brand experience toward resilience to negative information were fully mediated by brand attachment. Building ideal self-congruence and sensory brand experience will not directly increase consumers' forgiveness. Consumers' forgiveness is achieved through strong attachments.

\section{Managerial implications}

Marketers could use this study as guidance in understanding how to maximize brand attachment and leveraging consumers' forgiveness. Marketers could start developing marketing activities that support their consumers' ideal self. This can be achieved through creating an advertisement that fosters consumers' ideal self. For instance, Victoria's Secret has used supermodels Victoria's Secret Angels - in promoting their clothing lines. Apart from advertisements, marketers could create events that involve their consumers. For instance, General Motors created its 'Interactive Design Competition', catering for individuals' dreams of becoming a top professional designer.

Marketers also need to focus on creating and delivering brand experiences, in particular sensory experiences. These experiences may entice, enable, and enrich consumer's self (Schmitt, 2013). Firms should create a strategy that enhances consumers' experience. This can be achieved through creating a great experience in their retail store (e.g., ambience). 
People are wondering why there are so many Apple 'aficionados' that are willing to sacrifice their resources and defend the brand. This study displays that one of the reasons is that Apple delivers their brand's promise experiences. If one visits Apple's store, that individual is able to feel and test Apple's product to its full functions (e.g., access to the Internet). Previously, either there was no access to the Internet, because there was no connection available or because of limitations in the number of products available (e.g., only one or two PCs available).

Besides, a firm could create an event to deliver the brand's experiences. For example, for a car manufacturer launching a new car promising great off-road abilities, they could create an off-road event that allowed their consumers to actually test in a real situation compared to a regular test-drive. As an alternative, the firm can install the consumer as the passenger, while the car is being driven by a professional off-road driver. It should be noted that brand responsiveness is the strongest factor that influences the degree of attachment. Marketers should be able to enhance their consumers' sense of autonomy, relatedness, and competence. A firm should create a strategy that continuously attempts to understand consumers' interest, perspectives, and preferences (autonomy). Marketers could achieve this through sponsoring, creating, and managing a brand community (see Muniz \& O'Guinn, 2001). Regarding consumers' need for interaction (relatedness), a firm should display interest, energy, and involvement toward the consumer and convey that they are important and cared for. For instance, Smart USA created 'your smart. Your story.'. Through this 'share your story' program, smart users are able to post their story with the car. Furthermore, Smart USA holds 'meet and greet' events to connect their consumers. This program has increased not only the relationships between the owners with their surroundings, but also the relationships between the consumers and the brand. Subsequently, a firm should be able to provide a structure that 
support or enhance consumers' sense of competence. It has been noted that the choice of a wrong endorser could result in consumers feeling incompetent (see Thomson, 2006). Therefore, marketers should be very careful in creating campaigns and choosing endorsers.

Finally, marketers need to communicate and increase consumers' awareness of their CSR activities in order to build strong bonding with their consumers. It is important for a firm to create a two-way communication. A firm can create a proactive strategy that involves their consumers in communicating the CSR activities, specifically through purchasing programs, for instance, shoe company TOMS, with its 'one for one' program. TOMS gives their consumers a chance to participate in giving shoes to the children in need all over the US. Additionally, marketers can highlight their brand's emotional appeal through well thought-out activities that engender memorable experiences.

\section{Limitations and Future Research}

Though the present study offers a significant advance in understanding the drivers of brand attachment, it is not without limitations. It should be underlined that the inference of the causal relationships is from cross-sectional survey data. Similarly, the framework was tested with UK residents. Hence, a longitudinal study and the testing of the framework in a different cultural context are needed. Additionally, these psychology constructs were measured using measurements and techniques available from previous research; based on this analysis not all of the items loaded toward the constructs. This outcome should be examined further through future studies, to ascertain whether or not these measurements will load similarly to our study. In conjunction, future research should pay attention to alternative measurements. For instance, Jimenez and Voss (2014) propose an alternative approach to measure emotional attachment, using a one-dimensional scale that reflects the abstract nature of emotional attachment. 
Future research needs to examine other moderating variables that can influence the relationships between brand attachment and antecedents, as well as the relationships between brand attachment and any consequences. For instance, it has been discussed that although strong brand attachment leads to higher consumer resilience to negative information, this link can be attenuated by the magnitude of the mistakes. Therefore, it will be fruitful to test different levels of mistakes made by the brand, and how far consumer will go.

Further research is needed to investigate the negative consequences of brand attachment. Grégoire and Fisher (2006) put forward the notion of 'love is blind' and 'love becomes hate'. It has been noted by Johnson, Matear and Thomson (2011) that brand with high self-relevance can lead to negative consequences such as: payback and complaining behaviors. Thomson, Whelan and Johnson (2012) show that attachment style predicts anti-brand actions. Therefore, it is also possible that brand attachment leads to these negative behaviors. When does this occur? What factors cause it to occur? Further research is worth undertaking into what factors moderate or mediate the relationships between brand attachment and its negative consequences. 


\section{References}

Aaker, J. L. (1999). The malleable self: The role of self-expression in persuasion. Journal of Marketing Research, 36(1), 45-57.

Alba, J. W. and Hutchinson, J. W. (1987). Dimensions of consumer expertise. Journal of Consumer Research, 13(4), 411-454.

Anderson, R. E. and Srinivasan, S. S. (2003). E-satisfaction and e-loyalty: A contingency framework. Psychology and Marketing, 20(2), 123-138.

Arnould, E. J. and Price, L. L. (1993). River magic: Extraordinary experience and the extended service encounter. Journal of Consumer Research, 20(1), 24-45.

Bartz, J. A., \& Lydon, J. E. (2004). Close relationships and the working self-concept: Implicit and explicit effects of priming attachment on agency and communion. Personality and Social Psychology Bulletin, 30(11), 1389-1401.

Batra, R., Ahuvia, A. and Bagozzi, R. P. (2012). Brand love. Journal of Marketing, 76(2), 116.

Belk, R. W. (1988). Possessions and the extended self. Journal of Consumer Research, 15(2), 139-168.

Bhattacharya, C. B. and Sankar Sen. (2003) "Consumer-company identification: A framework for understanding consumers' relationships with companies." Journal of Marketing, 67(2), 76-88.

Bhattacharya, C. B. and Sen, S. (2004). Doing better at doing good: When, why, and how consumers respond to corporate social initiatives. California Management Review, 47(1), 9-24.

Bowlby, J. (1969). Attachment and Loss: Vol. 1. Attachment. New York: Basic Books.

Brakus, J. J., Schmitt, B. H. and Zarantonello, L. (2009). Brand experience: What is it? How is it measured? Does it affect loyalty? Journal of Marketing, 73(3), 52-68.

Brown, T. J. and Dacin, P. A. (1997). The company and the product: corporate associations and consumer product responses. Journal of Marketing, 61(1), 68-84.

Brown, T. J., Mowen, J. C., Donavan, D. T. and Licata, J. W. (2002). The customer orientation of service workers: personality trait effects on self-and supervisor performance ratings. Journal of Marketing Research, 39(1), 110-119.

Carroll, B. A., and Ahuvia, A. C. (2006). Some antecedents and outcomes of brand love. Marketing Letters, 17(2), 79-89.

Celsi, R. L., Rose, R. L. and Leigh, T. W. (1993). An exploration of high-risk leisure consumption through skydiving. Journal of Consumer Research, 20(1), 1-23.

Chandrashekaran, M., Rotte, K., Tax, S. S. and Grewal, R. (2007). Satisfaction strength and customer loyalty. Journal of Marketing Research, 44(1), 153-163.

Chaudhuri, A. and Holbrook, M. B. (2001). The chain of effects from brand trust and brand affect to brand performance: the role of brand loyalty. Journal of Marketing, 65(2), 8193.

Chung, E., and Beverland, M. (2006). An exploration of consumer forgiveness following marketer transgressions. Advances in Consumer Research, 33, 98-99.

Cowart, K. O., Fox, G. L., \& Wilson, A. E. (2008). A structural look at consumer innovativeness and self-congruence in new product purchases. Psychology \& Marketing, 25(12), 1111-1130.

Deci, E. L. and Ryan, R. M. (2000). The 'What' and 'Why' of Goal Pursuits: Human Needs and the Self-Determination of Behavior. Psychological Inquiry, 11(4), 227-268.

Du, S., Bhattacharya, C. and Sen, S. (2007). Reaping relational rewards from corporate social responsibility: The role of competitive positioning. International Journal of Research in Marketing, 24(3), 224-241. 
Du, S., Bhattacharya, C. B., \& Sen, S. (2010). Maximizing business returns to corporate social responsibility (CSR): The role of CSR communication. International Journal of Management Reviews, 12(1), 8-19.

Du, S., Bhattacharya, C. B., \& Sen, S. (2011). Corporate social responsibility and competitive advantage: Overcoming the trust barrier. Management Science,57(9), 1528-1545.

Ekinci, Y., Dawes, P. L. and Massey, G. R. (2008). An extended model of the antecedents and consequences of consumer satisfaction for hospitality services. European Journal of Marketing, 42(1/2), 35-68.

Ernst \& Young. (2011). This time it's personal: from consumer to co-creator. Available at: http://www.ey.com/Publication/vwLUAssets/This_time_it_is_personal__from_consumer_to_co-creator_2012/\$File/Consumer\%20barometer_V9a.pdf (accessed 20th of March 2014).

Escalas, J. E. (2004). Narrative processing: Building consumer connections to brands. Journal of Consumer Psychology, 14(1), 168-180.

Escalas, J. E. and Bettman, J. R. (2005). Self-construal, reference groups, and brand meaning. Journal of Consumer Research, 32(3), 378-389.

Fedorikhin, A., Park, C. W. and Thomson, M. (2008). Beyond fit and attitude: The effect of emotional attachment on consumer responses to brand extensions. Journal of Consumer Psychology, 18(4), 281-291.

Finkel, E. J., Rusbult, C. E., Kumashiro, M., and Hannon, P. A. (2002). Dealing with betrayal in close relationships: Does commitment promote forgiveness?.Journal of Personality and Social Psychology, 82(6), 956-974.

Fornell, C. and Larcker, D. F. (1981). Evaluating structural equation models with unobservable variables and measurement error. Journal of Marketing Research, 18(3), 39-50.

Fournier, S. (1998). Consumers and their brands: developing relationship theory in consumer research. Journal of Consumer Research, 24(4), 343-353.

Graeff, T. R. (1996). Image congruence effects on product evaluations: The role of selfmonitoring and public/private consumption. Psychology and Marketing, 13(5), 481499.

Grégoire, Y. and Fisher, R. J. (2006). The effects of relationship quality on customer retaliation. Marketing Letters, 17(1), 31-46.

Grisaffe, D. B., and Nguyen, H. P. (2011). Antecedents of emotional attachment to brands. Journal of Business Research, 64(10), 1052-1059.

Hair, J. F., Black, W. C., Babin, B. J. and Anderson, R. E. (2010). Multivariate data analysis: A Global Perspective: Pearson Education.

Hazan, C. and Shaver, P. R. (1994). Attachment as an organizational framework for research on close relationships. Psychological Inquiry, 5(1), 1-22.

Hong, J. W. and Zinkhan, G. M. (1995). Self-concept and advertising effectiveness: The influence of congruency, conspicuousness, and response mode. Psychology and Marketing, 12(1), 53-77.

Holt, D. B., Quelch, J. A., \& Taylor, E. L. (2004). "How Global Brands Compete”, Harvard Business Review, 9, pp. 68-75.

IBM (2010). Capitalizing on complexity: Insights from the global chief executive officers study. Availabe

at: http://public.dhe.ibm.com/common/ssi/ecm/en/gbe03297usen/gbe03297usen.pdf (accessed 12th of March 2014).

Jiménez, F. R. and Voss, K. E. (2014). An alternative approach to the measurement of emotional attachment. Psychology and Marketing, 31(5), 360-370. 
Johnson, A. R., Matear, M. and Thomson, M. (2011). A coal in the heart: Self-relevance as a post-exit predictor of consumer anti-brand actions. Journal of Consumer Research, 38(1), 108-125.

Kim, H. R., Lee, M. and Ulgado, F. M. (2005). Brand personality, self-congruity and the consumer-brand relationship. In Y. U. Ha and Y. Yi (Eds.), Asia Pacific Advances in Consumer Research (Vol. 6, pp. 111-117). Duluth, MN: Association for Consumer Research.

Kleine, S. S. and Baker, S. M. (2004). An integrative review of material possession attachment. Academy of Marketing Science Review, 1, 1-36.

Kotler, P. (2011). Reinventing marketing to manage the environmental imperative. Journal of Marketing, 75(4), 132-135.

Kressmann, F., Sirgy, M. J., Herrmann, A., Huber, F., Huber, S. and Lee, D. J. (2006). Direct and indirect effects of self-image congruence on brand loyalty. Journal of Business Research, 59(9), 955-964.

Krishna, A. (2006). Interaction of senses: The effect of vision versus touch on the elongation bias. Journal of Consumer Research, 32(4), 557-566.

Krishna, A. (2012). An integrative review of sensory marketing: Engaging the senses to affect perception, judgment and behavior. Journal of Consumer Psychology, 22(3), 332-351.

La Guardia, J. G. and Patrick, H. (2008). Self-Determination Theory as a Fundamental Theory of Close Relationships. Canadian Psychology, 49(3), 201-209.

La Guardia, J. G., Ryan, R. M., Couchman, C. E. and Deci, E. L. (2000). Within-person variation in security of attachment: A self-determination theory perspective on attachment, need fulfillment, and well-being. Journal of Personality and Social Psychology, 79(3), 367-384.

Lin, J. S. and Sung, Y. (2014). Nothing can tear us apart: The effect of brand identity fusion in consumer-brand relationships. Psychology and Marketing, 31(1), 54-69.

Luo, X. and Bhattacharya, C. B. (2006). Corporate social responsibility, customer satisfaction, and market value. Journal of Marketing, 70(4), 1-18.

Malär, L., Krohmer, H., Hoyer, W. D. and Nyffenegger, B. (2011). Emotional brand attachment and brand personality: the relative importance of the actual and the ideal self. Journal of Marketing, 75(4), 35-52.

Markus, H. (1983). Self-knowledge: An expanded view. Journal of Personality, 51(3), 543565.

Markus, H., Smith, J. and Moreland, R. L. (1985). Role of the self-concept in the perception of others. Journal of Personality and Social Psychology, 49(6), 1494-1512.

Mehta, A. (1999). Using self-concept to assess advertising effectiveness. Journal of Advertising Research, 39(1), 81-89.

Muniz Jr, A. M. and O'guinn, T. C. (2001). Brand community. Journal of Consumer Research, 27(4), 412-432.

Nam, J., Ekinci, Y. and Whyatt, G. (2011). Brand equity, brand loyalty and consumer satisfaction. Annals of Tourism Research, 38(3), 1009-1030.

Oliver, R. L. (1999). Whence consumer loyalty? Journal of Marketing, 63(4), 33-44.

Orth, U. R., Limon, Y. and Rose, G. (2010). Store-evoked affect, personalities, and consumer emotional attachments to brands. Journal of Business Research, 63(11), 1202-1208.

Park, C. W. and MacInnis, D. J. (2006). What's in and what's out: questions on the boundaries of the attitude construct. Journal of Consumer Research, 33(1), 16-18.

Park, C. W., MacInnis, D. J., Priester, J., Eisingerich, A. B. and Iacobucci, D. (2010). Brand attachment and brand attitude strength: Conceptual and empirical differentiation of two critical brand equity drivers. Journal of Marketing, 74(6), 1-17. 
Patrick, H., Knee, C. R., Canevello, A. and Lonsbary, C. (2007). The role of need fulfillment in relationship functioning and well-being: A self-determination theory perspective. Journal of Personality and Social Psychology, 92(3), 437-457.

Pullig, C., Netemeyer, R. G., and Biswas, A. (2006). Attitude basis, certainty, and challenge alignment: A case of negative brand publicity. Journal of the Academy of Marketing Science, 34(4), 528-542.

Reed, A. (2002). Social identity as a useful perspective for self-concept-based consumer research. Psychology and Marketing, 19(3), 235-266.

Reed, A. (2004). Activating the self-importance of consumer selves: Exploring identity salience effects on judgments. Journal of Consumer Research, 31(2), 286-295.

Reibstein, D. J., Day, G. and Wind, J. (2009). Guest editorial: Is marketing academia losing its way? Journal of Marketing, 73(4), 1-3.

Reichheld, F. F. (2003). The one number you need to grow. Harvard Business Review, 81(12), 46-54.

Schaefer, D. R. and Dillman, D. A. (1998). Development of a standard e-mail methodology: Results of an experiment. Public Opinion Quarterly, 62(3), 378-397.

Schmalz, S. and Orth, U. R. (2012). Brand attachment and consumer emotional response to unethical firm behavior. Psychology and Marketing, 29(11), 869-884.

Schmitt, B. (2013). The consumer psychology of customer-brand relationships: Extending the AA Relationship model. Journal of Consumer Psychology, 23(2), 249-252.

Shankar, V., Smith, A. K., \& Rangaswamy, A. (2003). Customer satisfaction and loyalty in online and offline environments. International Journal of Research in Marketing, 20(2), 153-175.

Shaver, P. R. and Mikulincer, M. (2005). Attachment theory and research: Resurrection of the psychodynamic approach to personality. Journal of Research in Personality, 39(1), 22 45.

Sirgy, M. J. (1982). Self-concept in consumer behavior: A critical review. Journal of Consumer Research, 9(3), 287-300.

Sirgy, M., Grewal, D., Mangleburg, T., Park, J.-O., Chon, K.-S., Claiborne, C., Johar, J. S. and Berkman, H. (1997). Assessing the predictive validity of two methods of measuring self-image congruence. Journal of the Academy of Marketing Science, 25(3), 229-241.

Stokburger-Sauer, N., Ratneshwar, S. and Sen, S. (2012). Drivers of consumer-brand identification. International Journal of Research in Marketing, 29(4), 406-418.

Thomson, M. (2006). Human brands: Investigating antecedents to consumers' strong attachments to celebrities. Journal of Marketing, 70(3), 104-119.

Thomson, M., MacInnis, D. J. and Park, C. W. (2005). The ties that bind: Measuring the strength of consumers' emotional attachments to brands. Journal of Consumer Psychology, 15(1), 77-91.

Thomson, M., Whelan, J. and Johnson, A. R. (2012). Why brands should fear fearful consumers: How attachment style predicts retaliation. Journal of Consumer Psychology, 22(2), 289-298.

Veloutsou, C. and Moutinho, L. (2009). Brand relationships through brand reputation and brand tribalism. Journal of Business Research, 62(3), 314-322.

Vlachos, P. A., Theotokis, A., Pramatari, K. and Vrechopoulos, A. (2010). Consumer-retailer emotional attachment: some antecedents and the moderating role of attachment anxiety. European Journal of Marketing, 44(9/10), 1478-1499.

Vlachos, P. A. and Vrechopoulos, A. P. (2012). Consumer-retailer love and attachment: Antecedents and personality moderators. Journal of Retailing and Consumer Services, 19(2), 218-228. 
Xie, Y. and Peng, S. (2009). How to repair customer trust after negative publicity: The roles of competence, integrity, benevolence, and forgiveness. Psychology and Marketing, 26(7), 572-589.

Yim, C. K., Tse, D. K. and Chan, K. W. (2008). Strengthening customer loyalty through intimacy and passion: roles of customer-firm affection and customer-staff relationships in services. Journal of Marketing Research, 45(6), 741-756. 


\section{Appendix: Measures}

\section{Ideal Self-Congruence}

[This brand] is a mirror image of the person I would like to be.

[This brand] is similar to the person I would like to be.

[This brand] is consistent with how I would like to be.

\section{Brand Experience: Sensory}

[This brand] makes a strong impression on my visual sense or other senses.

I find [this brand] interesting in a sensory way.

[This brand] does not appeal to my senses. (reversed)

\section{Brand Responsiveness}

When using [this brand], I feel free to be who I am.

When using [this brand], I feel cared about.

When using [this brand], I feel very capable and effective.

When using [this brand], I feel like a competent person.

\section{CSR Beliefs}

[This brand] is socially responsible brand.

[This brand] cares for its employees.

[This brand] has made a real difference through its socially responsible actions.

\section{Overall Brand Attachment}

To what extent is [this brand] part of you and who you are.

To what extent do you feel emotionally bonded to [this brand].

To what extent do your thoughts and feelings toward [this brand] come to you naturally and instantly.

To what extent does the word [this brand] automatically evoke many good thoughts about the past, present, and future.

\section{Brand Loyalty}

I will continue to purchase [this brand] even if it increases price.

I intend to keep purchasing [this brand].

I will recommend [this brand] to someone who seeks my advice.

\section{Resilience to Negative Information}

I forgive [this brand] when it makes mistakes.

I will forgive [this brand] for specific negative information.

I would think favorably of [this brand] upon hearing specific negative information.

Note: The figures in brackets represent the standardized path coefficients. 
$\underline{\text { Figure 1. Full Mediation Model }}$

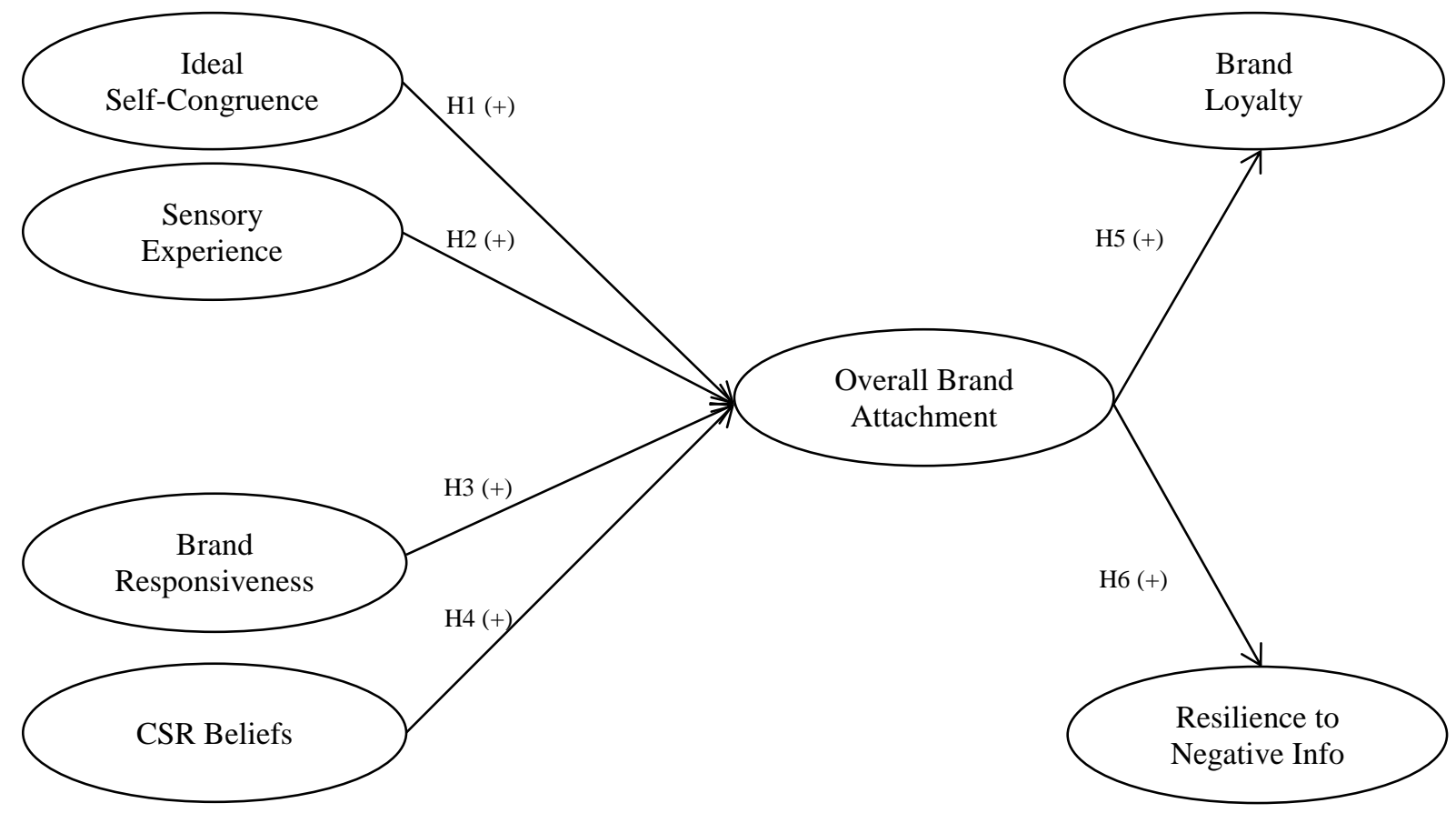


Figure 2. Partial Mediation Model

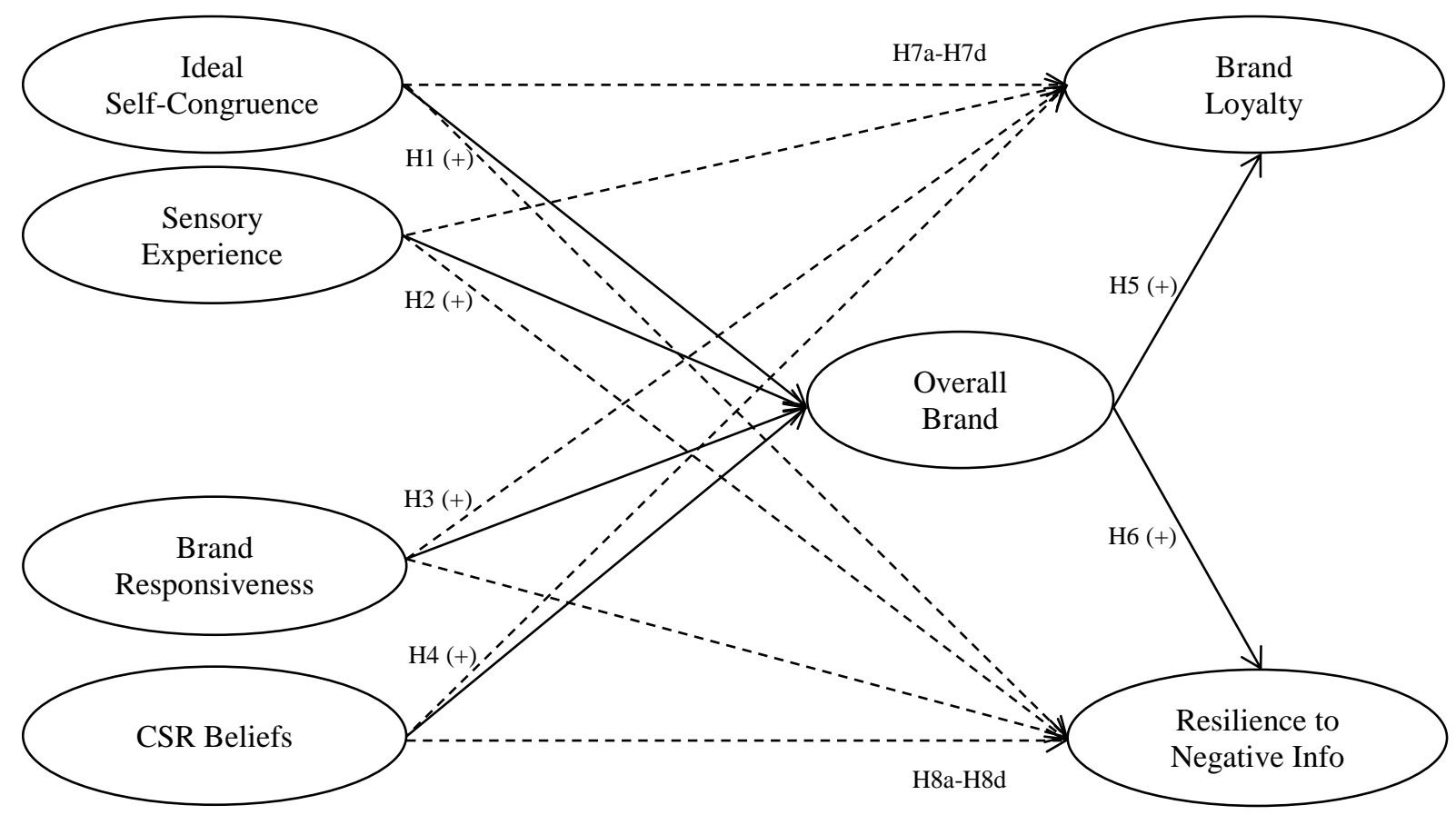


Table 1. Descriptive Statistics, Reliabilities, Correlations and Validities

\begin{tabular}{lccccccccccc}
\hline & Mean & SD & $\alpha$ & CR & 1 & 2 & 3 & 4 & 5 & 6 & 7 \\
\hline 1. ISC & 4.24 & 1.47 & 0.89 & 0.89 & $\mathbf{0 . 7 3}$ & 0.17 & 0.28 & 0.03 & 0.26 & 0.03 & 0.03 \\
2. SBE & 5.03 & 1.33 & 0.73 & 0.74 & 0.41 & $\mathbf{0 . 5 0}$ & 0.25 & 0.00 & 0.19 & 0.10 & 0.02 \\
3. BR & 4.32 & 1.34 & 0.82 & 0.82 & 0.53 & 0.50 & $\mathbf{0 . 5 4}$ & 0.05 & 0.36 & 0.05 & 0.12 \\
4. CSR & 4.82 & 1.08 & 0.77 & 0.78 & 0.16 & 0.05 & 0.22 & $\mathbf{0 . 5 4}$ & 0.06 & 0.05 & 0.08 \\
5. BA & 5.42 & 2.53 & 0.89 & 0.89 & 0.51 & 0.44 & 0.60 & 0.24 & $\mathbf{0 . 6 8}$ & 0.12 & 0.14 \\
6. BL & 5.89 & 1.02 & 0.80 & 0.81 & 0.18 & 0.31 & 0.22 & 0.22 & 0.35 & $\mathbf{0 . 5 9}$ & 0.08 \\
7. RNI & 4.15 & 1.18 & 0.73 & 0.75 & 0.17 & 0.15 & 0.35 & 0.29 & 0.37 & 0.28 & $\mathbf{0 . 5 2}$ \\
\hline
\end{tabular}

Note: ISC: Ideal Self-Congruence; SBE: Sensory Brand Experience; BR: Brand Responsiveness; CSR: Corporate Social Responsibility; BA: Brand Attachment; BL: Brand Loyalty; RNI: Resilience to Negative Information; The diagonal values in bold indicate the average variances extracted (AVE). The scores in the lower diagonal indicate inter-construct correlations (IC). The scores in the upper diagonal indicate squared IC (SIC). 
Table 2. Result of Structural Equation Analyses for Full and Partial Mediation Models

\begin{tabular}{|c|c|c|c|c|c|}
\hline \multirow{2}{*}{\multicolumn{2}{|c|}{ Relationships }} & \multicolumn{2}{|c|}{ Full mediation } & \multicolumn{2}{|c|}{ Partial mediation } \\
\hline & & SPC & t-value & SPC & t-value \\
\hline $\mathrm{H}_{1}$ & Ideal Self-Congruence $\rightarrow$ BA & 0.22 & $4.03 * *$ & 0.23 & $4.11 * *$ \\
\hline $\mathrm{H}_{2}$ & Sensory Brand Experience $\rightarrow$ BA & 0.15 & $2.56^{*}$ & 0.15 & $2.50 *$ \\
\hline $\mathrm{H}_{3}$ & Brand Responsiveness $\rightarrow$ BA & 0.38 & $5.78^{* *}$ & 0.38 & $5.70 * *$ \\
\hline $\mathrm{H}_{4}$ & CSR Beliefs $\rightarrow$ BA & 0.12 & $2.54 *$ & 0.11 & $2.32^{*}$ \\
\hline $\mathrm{H}_{5}$ & Brand Attachment $\rightarrow$ BL & 0.36 & $6.28 * *$ & 0.28 & $3.66^{* *}$ \\
\hline $\mathrm{H}_{6}$ & Brand Attachment $\rightarrow$ RNI & 0.37 & $6.33 * *$ & 0.26 & $3.45^{* *}$ \\
\hline $\mathrm{H}_{7 \mathrm{a}}$ & Ideal Self-Congruence $\rightarrow$ BL & & & -0.06 & -0.82 \\
\hline $\mathrm{H}_{7 \mathrm{~b}}$ & Sensory Brand Experience $\rightarrow$ BL & & & 0.23 & $3.07 * *$ \\
\hline $\mathrm{H}_{7 \mathrm{c}}$ & Brand Responsiveness $\rightarrow$ BL & & & -0.06 & -0.73 \\
\hline $\mathrm{H}_{7 \mathrm{~d}}$ & CSR Beliefs $\rightarrow$ BL & & & 0.17 & $2.77 * *$ \\
\hline $\mathrm{H}_{8 \mathrm{a}}$ & Ideal Self-Congruence $\rightarrow$ RNI & & & -0.10 & -1.40 \\
\hline $\mathrm{H}_{8 \mathrm{~b}}$ & Sensory Brand Experience $\rightarrow$ RNI & & & -0.03 & -0.40 \\
\hline $\mathrm{H}_{8 \mathrm{c}}$ & Brand Responsiveness $\rightarrow$ RNI & & & 0.21 & $2.51 *$ \\
\hline $\mathrm{H}_{8 \mathrm{~d}}$ & CSR Beliefs $\rightarrow$ RNI & & & 0.20 & $3.26 * *$ \\
\hline \multicolumn{6}{|c|}{ Model Fit Statistics } \\
\hline$\chi^{2}$ & & \multicolumn{2}{|c|}{442.68} & \multicolumn{2}{|c|}{407.71} \\
\hline$D f$ & & \multicolumn{2}{|c|}{218} & \multicolumn{2}{|c|}{210} \\
\hline \multicolumn{2}{|c|}{ RMSEA } & \multicolumn{2}{|c|}{0.05} & \multicolumn{2}{|c|}{0.05} \\
\hline \multicolumn{2}{|c|}{ SRMR } & \multicolumn{2}{|c|}{0.06} & \multicolumn{2}{|c|}{0.05} \\
\hline \multicolumn{2}{|c|}{ GFI } & \multicolumn{2}{|c|}{0.92} & \multicolumn{2}{|c|}{0.93} \\
\hline \multicolumn{2}{|c|}{ NFI } & \multicolumn{2}{|c|}{0.91} & \multicolumn{2}{|c|}{0.91} \\
\hline \multicolumn{2}{|c|}{ CFI } & \multicolumn{2}{|c|}{0.95} & \multicolumn{2}{|c|}{0.96} \\
\hline \multicolumn{6}{|c|}{ Variance explained $\left(\mathrm{R}^{2}\right)$} \\
\hline \multicolumn{2}{|c|}{ Brand Attachment } & \multicolumn{2}{|c|}{0.44} & \multicolumn{2}{|c|}{0.43} \\
\hline \multicolumn{2}{|c|}{ Brand Loyalty } & \multicolumn{2}{|c|}{0.13} & \multicolumn{2}{|c|}{0.18} \\
\hline \multicolumn{2}{|c|}{ Resilience to Negative Information } & \multicolumn{2}{|c|}{0.14} & & 20 \\
\hline
\end{tabular}

Note: SPC: Standardised Path Coefficient; BA: Brand Attachment; CSR: Corporate Social Responsibility; BL: Brand Loyalty; RNI: Resilience to Negative Information; Df: Degrees of freedom; RMSEA: Root Mean Square Error of Approximation; SRMR: Standardised Root Mean Residual; GFI: Goodness of Fit Index; NFI: Normed Fit Index; CFI: Comparative Fit Index; $* p<.05 ; * * p<.01$. 